\title{
Synthesis of Silver Doped Titanium Dioxide by Wet-Ball Milling Sol-Gel Method for Antibacterial Application
}

\author{
Tippabust EKSANGSRI ${ }^{*}$, Chaweewan SAPCHAROENKUN ${ }^{2}$, and Siripond Phromma ${ }^{2}$ \\ ${ }^{1}$ Thammasat School of Engineering, Thammasat University, 99 Phaholyothin Rd., Khlong Loung, Pathumthani 12120, Thailand \\ ${ }^{2}$ National Nanotechnology Center, National Science and Technology Development Agency, Pathumthani, 12120, Thailand
}

\begin{abstract}
Titanium dioxide $\left(\mathrm{TiO}_{2}\right)$ has been extensively studied as photo-catalyst for water treatment, air purification and antibacterial applications due to its challenging properties such as chemical stability, environmental friendly and strong photocatalytic activity. However, the limitation of $\mathrm{TiO}_{2}$ on its dependent to ultraviolet radiation for photocatalytic activity is still aroused. In this study, silver doped titanium dioxide $\left(\mathrm{Ag}-\mathrm{TiO}_{2}\right)$ was synthesized by wet-ball milling sol-gel method (WBMS). $\mathrm{Ag}-\mathrm{TiO}_{2}$ molar ratio was varied from $0 \%$ to $10 \%$ to study the effect of silver content on the synthesized $\mathrm{Ag}-\mathrm{TiO}_{2}$ characteristics and the ability to apply on antibacterial applications. The objective of this work was to find an optimal concentration of $\mathrm{Ag}$ in $\mathrm{Ag}-\mathrm{TiO}_{2}$. Characterization of the particle size, morphology, and surface area of synthesized $\mathrm{Ag}-\mathrm{TiO}_{2}$ were discussed by techniques of transmission electron microscopy (TEM) and Brunauer-Emmett-Teller (BET). Photocatalytic activity was investigated from degradation of methylene blue. Antibacterial activity was conducted by finding minimum inhibitory concentration (MIC) and minimum bactericidal concentration (MBC) tests performed on Escherichia coli (E. coli) and Staphylococcus aureus (S. aureus) under dark condition and under visible light. The results demonstrated that the doping of $\mathrm{Ag}$ inhibited crystal growth of $\mathrm{Ag}-\mathrm{TiO}_{2}$. The smallest particle size and the highest surface area were obtained from $5 \% \mathrm{Ag}-\mathrm{TiO}_{2}$. Also, it was found that methylene blue degradation rate increased to the highest number of $1.62 \times 10^{-3} \mathrm{~min}^{-1}$ when Ag concentration reached $5 \%$, and methylene blue degradation rate reduced when $\mathrm{Ag}$ concentration was higher than $5 \%$. The antibacterial activity of $\mathrm{Ag}-\mathrm{TiO}_{2}$ was better than $\mathrm{TiO}_{2}$. The optimal concentration of $3-5 \% \mathrm{Ag}-\mathrm{TiO}_{2}$ was observed from the $\mathrm{MIC}$ and MBC tests.
\end{abstract}

\section{Introduction}

Titanium dioxide $\left(\mathrm{TiO}_{2}\right)$ nanoparticle is photocatalyst has been widely researched in waste treatment applications due to its strong oxidizing property, non-toxicity and long-term photo stability (Zaleska, 2008). It has been also in the research interest for the antibacterial applications. However, the limitation of using $\mathrm{TiO}_{2}$ upon its dependency on UV light is prominent. To overcome this limitation of $\mathrm{TiO}_{2}$ nanoparticles, as well as enhancing the effectiveness of its photocatalytic and antibacterial activity, silver doped $\mathrm{TiO}_{2}\left(\mathrm{Ag}-\mathrm{TiO}_{2}\right)$ nanoparticle is proposed. In this study, $\mathrm{Ag}-\mathrm{TiO}_{2}$ was synthesized by wet ball milling sol-gel method (Phromma et al., 2017). Effect of silver concentration on the photocatalytic activity and antibacterial activity was investigated. Characterization of the particle size and morphology of synthesized Ag$\mathrm{TiO}_{2}$ were determined.

\section{Experimental}

\section{1 $\mathrm{Ag}-\mathrm{TiO}_{2}$ Preparation}

$\mathrm{Ag}-\mathrm{TiO}_{2}$ was synthesized by wet-ball milling sol-gel method, modified from the previous report (Phromma et al., 2017). The substitution reaction of Titanium (IV) isopropoxide $97 \%$ wt (TTIP) with methanol (MeOH) were carried out with a molar ratio of $1: 15$. The solution $\mathrm{pH}$ was adjusted to 2 by adding $2 \mathrm{ml}$ of $\mathrm{HNO}_{3}$. The various amount of $\mathrm{Ag}$ was added to the $\mathrm{TiO}_{2}$ solution in concentration of $3 \%, 5 \%, 6 \%$ and $10 \%$ by mole. The yellow colloid of $\mathrm{Ag}-\mathrm{TiO}_{2}$ was obtained. Citric acid was used to reduce $\mathrm{Ag}^{+}$into $\mathrm{Ag}^{0}$. The $\mathrm{Ag}-\mathrm{TiO}_{2}$ gel was then observed. Washing $\mathrm{Ag}-\mathrm{TiO}_{2}$ gel with $\mathrm{DI}$ water by centrifuged at 10,000 rpm for $15 \mathrm{~min}$, then the yellow gel was dried at $110^{\circ} \mathrm{C}$ for 24 hours. The yellow powder, then,

\footnotetext{
*orresponding author: etippabu@engr.tu.ac.th
} 
appeared. The yellow powder was dry ground with 10 mm-ball milling at $300 \mathrm{rpm}$ for $20 \mathrm{~min}$ and consequently wet ground by $2 \mathrm{~mm}$-ball milling at $500 \mathrm{rpm}$ for 3 hours in IPA. The $\mathrm{Ag}-\mathrm{TiO}_{2}$ solution was dried again at $110^{\circ} \mathrm{C}$ for 24 hours and was calcined at $400^{\circ} \mathrm{C}$ for 4 hours with a heating rate of $5^{\circ} \mathrm{C} / \mathrm{min}$. After all the processes mentioned, $\mathrm{Ag}-\mathrm{TiO}_{2}$ nanoparticle powder was synthesized. The nomenclature 3\% Ag- $\mathrm{TiO}_{2}, 5 \% \mathrm{Ag}-\mathrm{TiO}_{2}, 6 \% \mathrm{Ag}-\mathrm{TiO}_{2}$ and $10 \% \quad \mathrm{Ag}-\mathrm{TiO}_{2}$ are used to represent the various concentration of silver doped.

\subsection{Characterization of synthesized $\mathrm{Ag}-\mathrm{TiO}_{2}$}

The morphology and particle size distribution of $\mathrm{Ag}-\mathrm{TiO}_{2}$ were studied by high resolution transmission electron microscopy (HRTEM, JEOL JEM-2100) operated at 200 $\mathrm{kV}$. Brunauer-Emmett-Teller (BET) was used to determine surface area of $\mathrm{Ag}-\mathrm{TiO}_{2}$ particles. The degradation of methylene blue (MB), (Ajax Finechem), under UV radiation was used as a model system to evaluate the photocatalytic activity of $\mathrm{Ag}-\mathrm{TiO}_{2}$. The photocatalytic reaction was carried out in the in-house photocatalytic chamber. The initial concentration of $\mathrm{MB}$ $\left(\mathrm{C}_{0}\right)$ was prepared at $5 \mathrm{ppm}$. A $10-\mathrm{mg}$ of $\mathrm{Ag}-\mathrm{TiO}_{2}$ was mixed with $40 \mathrm{ml}$ of $\mathrm{MB}$ solution and then stirred in the photocatalytic chamber. The mixture was kept in the dark for $1 \mathrm{~h}$ to ensure the saturation of $\mathrm{MB}$ on the surface of the catalysts. The MB solution was irradiated by $0.25 \mathrm{UV}$ light $\mathrm{Wm}^{-2}(\lambda=351 \mathrm{~nm})$. The sample was collected at every hour for 24 hour. The concentration of MB in suspension was analyzed using a UV-Vis spectrophotometer at wavelength of $635 \mathrm{~nm}$. The kinetic constants of reaction rate were determined according to the pseudo-first-order kinetic model as follows:

$$
\ln \left(C / C_{0}\right)=-k t
$$

where $\quad t$ is the irradiation time

$$
\begin{aligned}
& k \text { is kinetic constant }\left(\mathrm{min}^{-1}\right) \text {, and } \\
& C \text { is the concentration of the } \mathrm{MB}(\mathrm{mg} / \mathrm{L}) \text {. }
\end{aligned}
$$

The antibacterial activity of the synthesized $\mathrm{Ag}-\mathrm{TiO}_{2}$ was investigated using the standard microdilution method. Minimum inhibitory concentration (MIC) that inhibited the growth of bacterial strain was determined on 96-well microdilution plates. Initial concentration of microorganisms (Staphylococcus aureus; S. aureus 8739 as a gram positive or Escherichia coli; E. coli $6538 \mathrm{P}$ as a gram negative bacteria) was $105 \mathrm{cfu} / \mathrm{ml}$. Preparation of Ag- $-\mathrm{TiO}_{2}$ solution by dissolved $10 \mathrm{mg} \mathrm{Ag}-\mathrm{TiO}_{2}$ in $10 \%$ dimethyl sulfoxide (DMSO) and make a serial dilution of $\mathrm{Ag}^{-} \mathrm{TiO}_{2}$ powder with Mueller-Hinton Broth (MHB). End point were determined when no turbidity in the 96-well was observed after 24 hours under dark and UV light condition of incubation at $37^{\circ} \mathrm{C}$ and $95 \%$ relative humidity. Minimum bacterial concentration (MBC) was also determined by counting colony on agar plates after incubated at $37^{\circ} \mathrm{C}$ for 24 hours.

\section{Results and Discussions}

From TEM images, as shown in Figure 1, silver distribution was observed as black particles scattering on white powder. The scattered silver particles came close to each other more when the silver concentration was higher. The agregation of particles seemed to be more obvious with higher silver amount added.

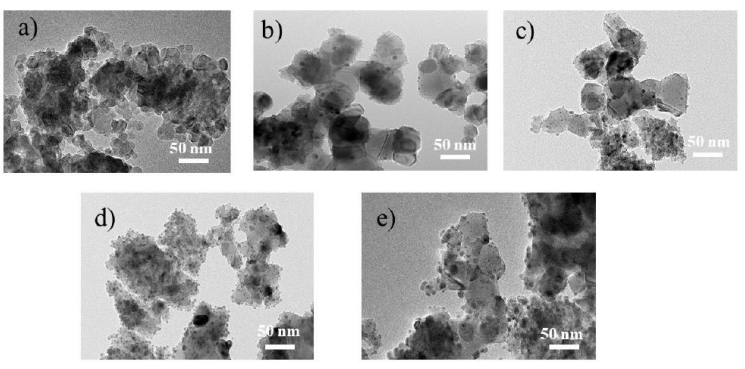

Figure 1. TEM images of synthesized $\mathrm{TiO}_{2}(\mathrm{a}), 3 \% \mathrm{Ag}-\mathrm{TiO}_{2}(\mathrm{~b})$, $5 \% \mathrm{Ag}_{-}-\mathrm{TiO}_{2}(\mathrm{c}), 6 \% \mathrm{Ag}-\mathrm{TiO}_{2}(\mathrm{~d})$ and $10 \% \mathrm{Ag}-\mathrm{TiO}_{2}$ (e)

As demonstrated in Table 1, particle size of $\mathrm{Ag}-\mathrm{TiO}_{2}$ increased from $16.4 \pm 5.2 \mathrm{~nm}$, when there was no Ag added, to $34.0 \pm 9.1 \mathrm{~nm}$ when it was $3 \% \quad \mathrm{Ag}-\mathrm{TiO}_{2}$. Higher concentration of silver, however, did not cause further increasing of the particle size. It stayed in a range of $21-$ $28 \mathrm{~nm}$. This pattern might be well-explained owning to the larger size of $\mathrm{Ag}+(\mathrm{ca} .126 \mathrm{pm})$ when compared to the size of $\mathrm{Ti} 4+(\mathrm{ca} .68 \mathrm{pm})$. With small amount of silver added, the possibility of silver doped in the lattice of $\mathrm{TiO}_{2}$ is greater, and expand the particle size of the $\mathrm{Ag}-\mathrm{TiO}_{2}$. When more silver was added, however, silver ion rather stayed on the outer surface of the $\mathrm{TiO}_{2}$ than doped into the structure. The $\mathrm{Ag}+$ dispersed on surface of $\mathrm{TiO}_{2}$ effect the density of surface increased defect at the surface of anatase grain which favors the rutile nucleation (Chao et al., 2003). Then, surface area of $3 \% \mathrm{Ag}-\mathrm{TiO}_{2}$ decreased from 18.62 to $13.97 \mathrm{~m} 2 / \mathrm{g}$ as shown in Table1 due to large particle size of $3 \% \mathrm{AgTiO}_{2}$. Increasing of molar ratio of $\mathrm{Ag}$ from $5 \%$ to $6 \%$, the particle size decreased from $23.0 \pm 7.4 \mathrm{~nm}$ to $21.8 \pm 7.2 \mathrm{~nm}$. Since the Ag doping in optimum molar ratio usually hinders the growth of particle size (Ahmad et al., 2007). The highest surface area was obtained at 5\% $\mathrm{AgTiO}_{2}$. Moreover, when molar ratio of $\mathrm{Ag}$ increased from $6 \%$ to $10 \%$, the particle size was increased to $28.5 \pm 9.6 \mathrm{~nm}$ relative with decreasing of surface area. Then, $10 \% \mathrm{Ag}-\mathrm{TiO}_{2}$ showed agglomeration of nanoparticle since it presented high surface energy of the particle which the particle size of $\mathrm{TiO}_{2}$ is not limit of growth. 
Table 1. Particle size and BET surface area of synthesized $\mathrm{TiO}_{2}$ and $\mathrm{Ag}-\mathrm{TiO}_{2}$

\begin{tabular}{|c|c|c|}
\hline Sample & Particle size $(\mathrm{nm})$ & Surface area $\left(\mathrm{S}_{\mathrm{BET}} \mathrm{m}^{2} / \mathrm{g}\right)$ \\
\hline $\mathrm{TiO}$ & 18.62 \\
\hline $3 \% \mathrm{Ag} \cdot \mathrm{TiO} O_{2}$ & $16.4 \pm 5.2$ & 13.97 \\
\hline $5 \% \mathrm{Ag} \cdot \mathrm{TiO}_{2}$ & $34.0 \pm 9.1$ & 32.12 \\
\hline $6 \% \mathrm{Ag} \cdot \mathrm{TiO}_{2}$ & $23.0 \pm 7.4$ & 27.52 \\
\hline $10 \% \mathrm{Ag}-\mathrm{TiO}_{2}$ & $21.8 \pm 7.2$ & 30.25 \\
\hline
\end{tabular}

Figure 2 showed photocatalytic activity of $\mathrm{TiO}_{2}$ and Ag$\mathrm{TiO}_{2}$ with the degradation of MB solution under UV light and calculated the kinetic constant rate $(k)$ as shown in Table 2. It was shown that the photocatalytic activity of Ag- $-\mathrm{TiO}_{2}$ were higher than $\mathrm{TiO}_{2}$ powder with kinetic constant rate increased from $1.03 \times 10^{-3} \mathrm{~min}^{-1}$ to $1.62 \times 10^{-3}$ $\mathrm{min}^{-1}$ The highest photocatalytic activity with the kinetic constant of $1.62 \times 10^{-3} \mathrm{~min}^{1}$ was obtained with $5 \% \mathrm{Ag}_{-} \mathrm{TiO}_{2}$. This result was compliant to the highest surface area of $5 \% \mathrm{Ag}-\mathrm{TiO}_{2}$ as discussed earlier. When $\mathrm{Ag}-\mathrm{TiO}_{2}$ was increased from $6 \%$ to $10 \%$, the photocatalytic activity decreased as can be seen by the decreasing of kinetic constant to $1.53 \times 10^{-3} \mathrm{~min}^{-1}$. Since a large silver nanoparticle hindered UV absorption onto $\mathrm{TiO}_{2}$, in consequence, the degradation of $\mathrm{MB}$ was slower.

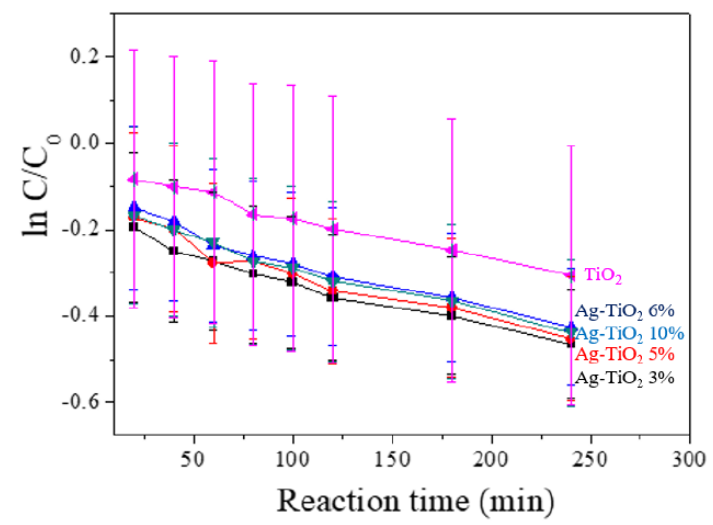

Figure 2. Photocatalytic reaction rates of $\mathrm{MB}$ degradation with different silver concentration in $\mathrm{Ag}-\mathrm{TiO}_{2}$

Table 2. Kinetic constant of MB degradation

\begin{tabular}{|c|c|}
\hline Sample & $\begin{array}{c}\text { Kinetic constant rate } \\
\left(\mathrm{kx} 10^{-3} \mathrm{~min}^{-1}\right)\end{array}$ \\
\hline $\mathrm{TiO}$ & 1.03 \\
\hline $3 \% \mathrm{Ag}-\mathrm{TiO}_{2}$ & 1.12 \\
\hline $5 \% \mathrm{Ag}-\mathrm{TiO}_{2}$ & 1.62 \\
\hline $6 \% \mathrm{Ag}-\mathrm{TiO}_{2}$ & 1.57 \\
\hline $10 \% \mathrm{Ag}-\mathrm{TiO}_{2}$ & 1.53 \\
\hline
\end{tabular}

The MIC of $\mathrm{TiO}_{2}$ and $\mathrm{Ag}-\mathrm{TiO}_{2}$ with different concentrations was estimated by using Staphylococcus aureus (S. aureus) 8739 as a gram positive and Escherichia coli (E. coli) $6538 \mathrm{P}$ as a gram negative bacteria. Table 3 show MIC of $\mathrm{TiO}_{2}$ and $\mathrm{Ag}-\mathrm{TiO}_{2}$ with different concentrations under dark and UV light condition. The results showed that neither MIC nor MBC of microorganism growth could not be found in case of using $\mathrm{TiO}_{2}$ under dark condition. This is obvious that the antibacterial applications using $\mathrm{TiO}_{2}$ solely cannot be acheived due to its dependance to UV light.

Table 3. MIC and MBC for S. aureus and E. coli

\begin{tabular}{|c|c|c|c|c|c|c|c|c|}
\hline \multirow{3}{*}{ Sample } & \multicolumn{4}{|c|}{ MIC (mgml) } & \multicolumn{4}{|c|}{ MBC (mgml) } \\
\hline & \multicolumn{2}{|c|}{ E.coli } & \multicolumn{2}{|c|}{ S. aureus } & \multicolumn{2}{|c|}{ E. coli } & \multicolumn{2}{|c|}{ S. aureus } \\
\hline & Dark & UV light & Dark & UV light & Dark & UV light & Dark & UV light \\
\hline $\mathrm{TiO}_{2}$ & & 1.250 & - & 1.250 & & 10.000 & & 10.000 \\
\hline $3 \% \mathrm{Ag}_{-}-\mathrm{TiO}_{2}$ & 0.625 & 0.625 & 1.250 & 1.250 & 2.500 & 1.250 & 2.500 & 2.500 \\
\hline $5 \% \mathrm{Ag}^{-\mathrm{TiO}_{2}}$ & 0.625 & 0.625 & 1.250 & 1.250 & 1.250 & 1.250 & 1.250 & 2.500 \\
\hline $6 \% \mathrm{Ag}-\mathrm{TiO}_{2}$ & 0.625 & 1.250 & 1.250 & 1.250 & 1.250 & 2.500 & 2.500 & 2.500 \\
\hline $10 \% \mathrm{Ag}-\mathrm{TiO}_{2}$ & 0.312 & 0.625 & 0.625 & 1.250 & 0.625 & 0.625 & 5.000 & 2.500 \\
\hline
\end{tabular}

Considering MIC obtained when using different concentrations of $\mathrm{Ag}-\mathrm{TiO}_{2}$, it was clearly seen that the bacteria growth can be inhibited even in the dark condition when silver is doped to $\mathrm{TiO}_{2}$. MIC of E. coli and $\mathrm{S}$. aureus were the same when $3 \% \mathrm{Ag}-\mathrm{TiO}_{2}, 5 \% \mathrm{Ag}-\mathrm{TiO}_{2}$, and $6 \% \mathrm{Ag}-\mathrm{TiO}_{2}$ were used with both dark and UV-light conditions. However, the MIC was decreased to almost half when $10 \% \mathrm{Ag}^{-\mathrm{TiO}_{2}}$ was applied. It might be able to explain that $10 \% \mathrm{Ag}-\mathrm{TiO}_{2}$ showed the highest percentage of silver nanoparticles which affect directly to bacteria cell and cause its death.

The MBC is smaller when $\mathrm{Ag}-\mathrm{TiO}_{2}$ was used in UVlight condition, indicating that the synegistic effect of bacteria degradation by titanium and silver was presented. The MBC of $\mathrm{E}$. coli and $\mathrm{S}$. aureus under UV-light condition of $\mathrm{TiO}_{2}$ showed the highest amount of $10 \mathrm{mg} / \mathrm{ml}$ to kill bacteria. On the other hand, $\mathrm{Ag}-\mathrm{TiO}_{2}$ gave lower amount of concentration to kill bacteria. Therefore, Ag$\mathrm{TiO}_{2}$ showed the higher antibacterial activity than $\mathrm{TiO}_{2}$. $\mathrm{MBC}$ of E. coli of $3 \% \mathrm{Ag}-\mathrm{TiO}_{2}$ under UV light was at $0.625 \mathrm{mg} / \mathrm{ml}$ which is twice lesser than that of the dark condition at $1.250 \mathrm{mg} / \mathrm{ml}$. As $\mathrm{MBC}$ of $\mathrm{S}$. aureus under dark and UV light conditions were the same at 2.500 $\mathrm{mg} / \mathrm{ml}$. It suggested that $\mathrm{S}$. aureus is more resistant than E. coli. As can be seen when $5 \% \mathrm{Ag}-\mathrm{TiO}_{2}$ was used, $\mathrm{MBC}$ of E. coli was less than that os $\mathrm{S}$. aureus. When increasing silver concentration to $6 \% \mathrm{Ag}-\mathrm{TiO}_{2}-10 \% \mathrm{Ag}-\mathrm{TiO}_{2}$, however, $\mathrm{MBC}$ of $\mathrm{E}$. coli and $\mathrm{S}$. aureus were the same. The lowest MBC of E. coli is showed when using 3\% Ag$\mathrm{TiO}_{2}-5 \% \mathrm{Ag}-\mathrm{TiO}_{2}$ and $\mathrm{MBC}$ of $\mathrm{S}$. aureus also the same value at $2.500 \mathrm{mg} / \mathrm{ml}$. It was proved that the antibacterial activity of $\mathrm{Ag}-\mathrm{TiO}_{2}$ is higher than that of $\mathrm{TiO}_{2}$. Looking back to the images shown in Figure 1, it can be seen that Ag nanoparticle tends to deposit on $\mathrm{TiO}_{2}$ surface. The deposited Ag can be oxidized with oxygen to generate $\mathrm{Ag}+$ ion. $\mathrm{Ag}+$ ion can attack the cell wall of bacteria and diffuse into the cytoplasm leading to the cell death. Moreover, $\mathrm{TiO}_{2}$ makes photocatalytic reaction happened and generate reactive oxygen species that can kill bacteria. Furthermore, from the results we obtained the higher value $\mathrm{MBC}$ of $\mathrm{S}$. aureus than $\mathrm{E}$. coli is because the difference in cell wall structure between gram positive and gram negative bacteria. Because gram negative consists of a thin peptidoglycan layer (PG) So, gram negative bacteria can be attacked easier than gram positive. 


\section{Conclusion}

Doping silver to $\mathrm{TiO}_{2}$ nanoparticles by WBMS method are successful. It results in modifying the lattice structure of $\mathrm{TiO}_{2}$ nanoparticle and cause the different size and surface area depending on the concentration of silver doping. The synthesized $\mathrm{Ag}-\mathrm{TiO}_{2}$ nanoparticle shows higher performance on antibacterial applications when compared to $\mathrm{TiO}_{2}$. The optimal amount of $\mathrm{Ag}$ in $\mathrm{TiO}_{2}$ is $5 \%$ by mole. It shows the highest photocatalytic activity with kinetic constant rate $1.62 \times 10^{-3} \mathrm{~min}^{-1}$. Antibacterial activities of $3 \% \mathrm{Ag}-\mathrm{TiO}_{2}$ and $5 \% \mathrm{Ag}-\mathrm{TiO}_{2}$ for E. coli and $\mathrm{S}$. aureus are the highest and higher than those of $\mathrm{TiO}_{2}$ as well.

\section{Acknowledgements}

This work was financially supported by National Nanotechnology Center (NANOTEC), National Science and Technology Development Agency (NSTDA), Thammasat School of Engineering, and Thailand Graduate Institute of Science and Technology (TGIST).

\section{References}

Ahmad, A., J. Thiel, and S. I. Shah; "Structural Effects of Niobium and Silver Doping on Titanium Dioxide Nanoparticles," Journal of Physics: Conference Series, 61, $11-15$ (2007)

Chao, H. E., Y. U. Yun, H. U. Xingfang, and A. Larbot; "Effect of Silver Doping on the Phase Transformation and Grain Growth of Sol-Gel Titania Powder," Journal of the European Ceramic Society, 23, 1457-1464 (2003)

Phromma, S., C. Sapcharoenkun, T. Wutikhun, P. Kasamechonchung, and T. Eksangsri; "Synthesis of $\mathrm{TiO}_{2}$ Nanoparticles with High Photocatlytic Activity by Wet Ball Milling Solgel Method," Proceeding of Research, Innovative Chemical Engineering and Technology toward a Sustainable Future, pp. 211-214, Bangkok, Thailand (2017)

Zaleska, A.; "Doped-TiO 2 : a Review," Recent Patents on Engineering, 2(3), 157-164 (2008) 